\title{
窒素ガスふん囲気中で作製したアルミニウム 焼結体とその陽極酸化についての研究
}

\author{
大 熊 貞 雄* ・根 本 富 弘*
}

\section{The authors have already reported on sintered body of aluminum and its anodic oxidation}

\section{Sadao OKUMA and Tomihiro NEMOTO}

In this study, an anodic oxidation was made by electrolysis by using a sintered body of aluminum prepared in nitrogen atmosphere as anode and ammonium dihydrogen phosphate as electrolyte A dielectric element thus obtained was made into a solid electrolytic condenser by coating with manganese dioxide $\left(\mathrm{MnO}_{2}\right)$ as semiconductor. That is : a solid electrolytic condenser of sintered sluminum was prepared. Experiments were conducted to examine the effects of particle size of aluminum powder and compacting pressure on electric characteristics of the condenser. The particle size in the experiments was of 4 kinds : 20, 35 150, 150 200, and $200 \mathrm{mesh}$, and the compacting pressure applied was 0.1 and $0.2 \mathrm{t}$. The capacitance at $120 \mathrm{~Hz}$ was assumed to be 100 as a standard and the ratio of capacitance at each frequency was considered for examination. As the results of experiments, it was observed that the capacitance ratio at each frequency was smaller and the value of $\tan \delta$ was larger with the decrease in particle size of aluminum powder, and there were little differences between the effects of 0.1 and $0.2 \mathrm{t}$ of compacting pressure.

\section{1. 緒 霉}

金属の酸化物を誘電体とするコンデンサにおいては, 酸化皮膜の厚サが一定であるとすれば，表面積の増大に よって電気容量を増加させることができる。タンタル電 解コンデンサの陽極素子においては, おむにタンタル粉 末の焼結体を化成したものを用いている。この焼結体を 用いている理由は, タンタル板やハクでは薬品に対する 反応性が小さいため電解エッチングや化成の処理 を技術的に十分行なえないからである。すなわち タンタル板やハクでは再現性を得にくいのであ る。これに対し, アルミニウム電解コンデンサに おいては，原料として报もにアルミニウムハクま たは板を用いている。これはタンタルとは逆にフ ルミニウム粉末は比較的, 融点 $\left(658.6^{\circ} \mathrm{C}\right)$ が低 く，酸化されやすい金属であるため焼結しにくい と考兄られていたからである。筆者らはアルミニ ウム粉末の焼結は真空中で可能であると考兄，行

* 東京電機大学応用理化学科（東京都千代田区神田錦 町 2-2) Department of Applied Science, Tokyo Electrical Engineering College.
なったところ成功し，かつアルミニウムの焼結機構を明 らかにした。これらの結果を用いて焼結体をつくり，さ らにそれに陽極化成を行なって誘電体素子を作製し，そ の電気的特性を測定した。

この結果，アルミニウム焼結体からの誘電体は多孔質 で表面積をより大きくとれることから，アルミニウム板 や八クからの誘電体と比較して $1 \mathrm{~cm}^{2}$ あたり約 3 倍程度 の電気的容量を得た。今回は窒素ガス中でアルミニウム

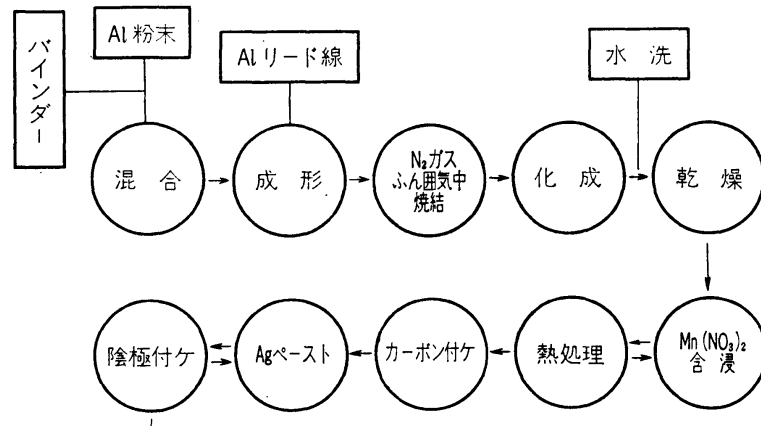

図1 $\mathrm{N}_{2}$ ガスふん囲気中で焼結 アルミニウム焼結形固体電 解コンデンサの製作工程図 


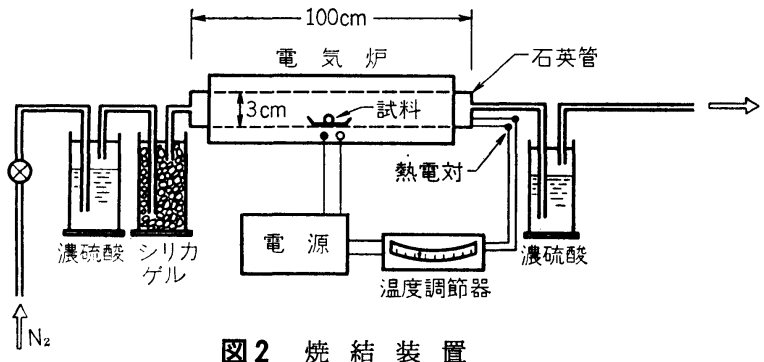

図 2 焼結装置

粉末の焼結を行ない, 得られた焼結体をりン酸二水素フ ソモニウム溶液を化成液として，陽極化成を行なった誘 電体素子を作製した。つぎにこの誘電体素子に半導体の 二酸化マンガン付ケをして固体電解コンデンサ化を行な った。すなわちアルミニウム焼結形固体電解コンデンサ を作製した。そしてこの電解コンデンサの電気的特性を 測定し, 測定值がアルミニウム粉末の粒度, 成形条件 などにどのように影響されるかを調べた。図1はアルミ ニウム焼結形固体電解コンデンサのフローシートであ る。

\section{2. 実験方法}

\section{2-1 成 形}

20，35〜150，150〜200，および200メッシニのそれぞ れの粒度のカイ状アルミニウム粉末にバインダーとし て，できるだけ少量のショウノウ（5 wt％以下）をエチ ルアルコールまたはエーテルで溶解して加える。 0.1 ま たは0.2 $\mathrm{t}$ の成形圧で $5 \mathrm{~mm} \phi \times$ 約 $5 \mathrm{~mm} \mathrm{~h}$ の円筒形に成 形した。この成形圧は前回報告7)*(p 209, 四10) したよう に成形圧と電気的特性との関係から選んだるのである。

\section{2-2 焼 結}

成形素子は 1 気圧の窒素ガ ス 中で注意深く温度を上 げ, $600^{\circ} \mathrm{C} て ゙ 120 〜 180 \mathrm{~min}$ 間焼結を行なった。この600 ${ }^{\circ} \mathrm{C}$ の焼結温度も前回の報告7)*(p 209, 四13) から選んだも のである。図 2 は焼結装置を示した。

\section{2-3 化 成}

一般にコンデンサ素子を化成する場合には，化成前に その表面状態を化成しやすい状態にするために化学薬品 を使用して前処理を行なっている。この研究では焼結体 の電気的特性を調べる目的を持っているので，化成前の 前処理は特に行なわなかった。化成液としてはホウ酸フ ソモニウム $\left(\mathrm{NH}_{4}\right)_{8} \mathrm{BO}_{3}$, リン酸二水素アンモニウム $\mathrm{NH}_{4} \mathrm{H}_{2} \mathrm{PO}_{4}$, クエン酸アンモニウム $\left(\mathrm{NH}_{4}\right)_{3} \mathrm{C}_{6} \mathrm{H}_{5} \mathrm{O}_{7}$, ホ ウ酸 $\mathrm{H}_{3} \mathrm{BO}_{3}$ などがあげられる。今回, 実験に用いた化 成液は濃度 $0.3 \%$ $3 \%$ 酸二水素アンモニウム溶液を用 いた。化成については50mA の定電流で $150 \mathrm{~V}$ まて電圧 をあげ， $150 \mathrm{~V}$ の一定電圧を保たせるために，電流を 2

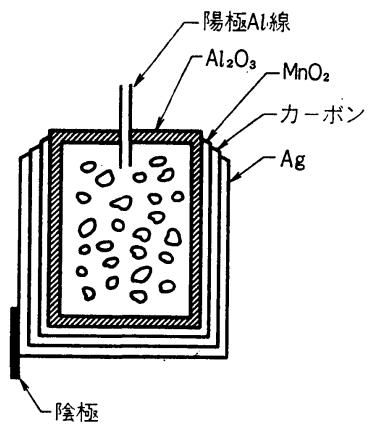

図 3 アルミニウ ム焼結形固体 電解コンデン サの構造図

$\mathrm{mA}$ まで下げた。すなわち定電流, 定電圧化成を行なっ た。化成した素子は水道水を60min 間流しつづけて洗浄 した後, 温度 $500^{\circ} \mathrm{C}$ で $60 \mathrm{~min}$ 間加熱乾燥した。また耐電 王とリン酸二水素アンモニウム溶液の濃度との間係を調 べる実験では，その溶液の濃度は $0.03 〜 0.8 \%$ 範囲で 用いた。

\section{2-4 固 体 化}

化成後の素子は飽和硝酸マンガン溶液 $\mathrm{Mn}\left(\mathrm{NO}_{8}\right)_{2}$ に なるべく短時間，ここでは10 min 間含浸した。硝酸マン ガンを含漫した素子は温度, $300^{\circ} \mathrm{C}$ で $60 \mathrm{~min}$ 間, 加熱し て熱分解を行ない，硝酸マンガンを半導体の性質をるつ 二酸化マンガン $\mathrm{MnO}_{2}$ に変え, 固着させた。

\section{2-5 仕 上}

固体化の終わった素子はコロイダルカーボンを塗り， $150^{\circ} \mathrm{C}$ で30 min 間加熱乾燥し，つぎに銀ぺイントを塗

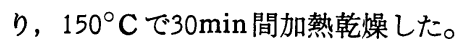

これらの仕上操作は，二酸化マンガン層と陰極の電気 的接触を良好にさせるためである。図 3 は試作したアル ミニウム焼結形固体電解コンデンサの構造図である。

\section{2-6 電気的特性の測定}

試作したアルミニウム焼結形固体電解コンデンサにつ いての電気的特性のうち, 電圧-電流特性 ( V-I 特性), 耐電圧, 容量 $(120 \mathrm{~Hz} \sim 10 \mathrm{KHz}, 1 \mathrm{~V}, \mathrm{AC}+3 \mathrm{~V}, \mathrm{DC}$ 重畺), $\tan \delta$ およびモレ電流などを固体測定法によって 測定 を行なった。

測定器は横河電機製, 万能ブリッジ BV-Z-13A を使 用した。

\section{3. 実験 結 果}

上述の方法で試作した素子はつぎのような種々の測定 を行なって実験結果を得た。

\section{3-1 奄圧-電流特性（V-I 特性）}

$0 \sim 10 \mathrm{~V}$ の印加電圧の範囲内での電流值を測定した。 そして粒度および 成形圧の電圧一電流特珄におよぼす影 響を調べだ。

これらの関係は図 4 に示した。これによると電圧-電 
流特性は，粒度の相違による影響は ほとんどないように思われる。また 同じ粒度をるつ誘電体素子の電圧電 流特性は，成形圧0.2 t の場合が0.1 $\mathrm{t}$ と比較して曲線がゆるやかであ る。

\section{3 -2 耐 電 圧}

測定の結果，各素子はおよそ4〜 $8 \mathrm{~V}$ の耐電圧の值を示した。そして 成形圧と化成液, リン酸二水素アン モニウム溶液の濃度が耐電圧におよ ぼす影響を調べ，この関係を図 5 に 示した。

\section{3-3 周波数特性および温度特性}

周波数は $120 ， 300 ， 800 ， 1 \mathrm{~K}$ ， $3 \mathrm{~K}, 8 \mathrm{~K}$ および $10 \mathrm{KHz}$ の 6 種類と 温度は $20^{\circ}, 40^{\circ}, 60^{\circ}$ おび $80^{\circ} \mathrm{C}$ の 4 種類を組み合わせ て測定を行なった。これらの関係はそれぞれ図 6 および 図7亿示した。

\section{3-4 容量比特性}

容量については相互関係を調べるために，120Hz の容 量測定値のみを注視するだけでは十分な考察が行なえな いきらいがある。そこで $120 \mathrm{~Hz}$ に打ける容量を100 と し，これに対する各周波数に括汀る容量比が粒度, 成形 圧および温度とどのような関係があるかを調べた。そし てこの関係を図 8 および図 9 に示した。

\section{4. 考察}

\section{4-1 電压-電流特性}

図 4 から同じ電圧を印加した場合， $0.2 \mathrm{t}$ は0.1 t と比 較して流れる電流は小さい。誘電体材料としては抵抗值 の大きいことが望ましい。

したがって0.2 t の成形圧で試作した誘電体素子は0.1 $\mathrm{t}$ のものより，やや良好であると考学られる。

\section{4-2 耐 電 王}

同じ粒度をもつ誘電体素子について，成形圧の耐電圧 飞抢よぼす影響は，0.1 t と0.2t の場合とでは，ほとん ぞないように思われる。電解コンデンサをつくるための 化成液には種々あるが，この実験にはリン酸二水素アン モニウム溶液を用いた。耐電圧の化成液の濃度による影 響は, リン酸二水素アンモニウム溶液 $\mathrm{NH}_{4} \mathrm{H}_{2} \mathrm{PO}_{4}$ を比 較的，らすい濃度範囲で使用したわけであるが，濃度 $0.1 \%$ とき，耐電圧がもっとも小さいといら結果が現 われた。一般に電解によってつくられる化成皮膜の成長 は，そのもとの金属の溶解反応の競合によって進むと考 えられる。このことから濃度 $0.1 \%$ 付近では, 他の濃度 と比べて金属の溶解が進み，薄い化成皮膜層を形成して

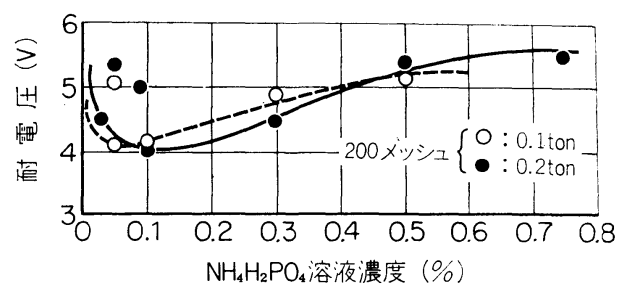

図 5 リン酸二水素アンモニウム溶夜濃度と酎電圧

いるものと考えられる。

\section{4一3 容量および $\tan \delta$ の周波数特性}

粒度の大きいほど (メッシュで表わした場合)，すな わら粒子の小さいアルミニウム粉末を原料として作製し た誘電体素子ほど，容量と $\tan \delta$ が大きくなった。これ は200メッシュのアルミニウム粉末からつくった素子は 20, 35〜150, 150〜200xッシュのものと比べてもっと も大きな表面積をもち，したがって大きな容量が得られ たものと考えられる。またこの実験では成形圧の影響は ほとんぞみられなかった。このことは附電圧の場合と同 じく，0.1 t と0.2 t の成形圧でつくられた焼結素子はア ルミニウムの金属組織が同じこと，すなわちアルミニウ ム粒子の間隔などが同じ状態にあることに起因すると考 えられる。前回報告したことは，まず真空中でのアルミ ニウム粉末の焼結であり，つぎにホウ酸アンモニウム溶 液 $\left(\mathrm{NH}_{4}\right)_{3} \mathrm{BO}_{3}$ を使用しての化成であり，そして電気的 特性の測定は液測法であった。したがって今回の実験で の容量, $\tan \delta$ の測定值と相違することは当然なことで ある。しかし今回の実験での粒度および成形圧の影響 は, 前回の報告7)*(p209, 図10)にある傾向とほとんど一致し ている。な抗この実験での容量および $\tan \delta$ の周波数特 性の傾向は一般のアルミニウム電解コンデンサとまった 


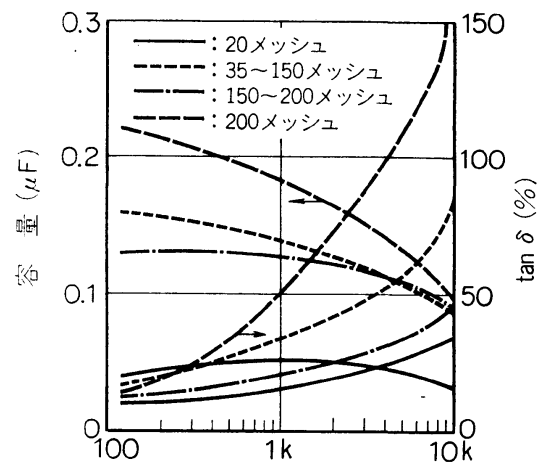

周 波 数 $(\mathrm{Hz})$

図 6 容量と $\tan \delta$ の周波数特性 (成形圧 $0.2 \mathrm{t}, 20^{\circ} \mathrm{C}$ )

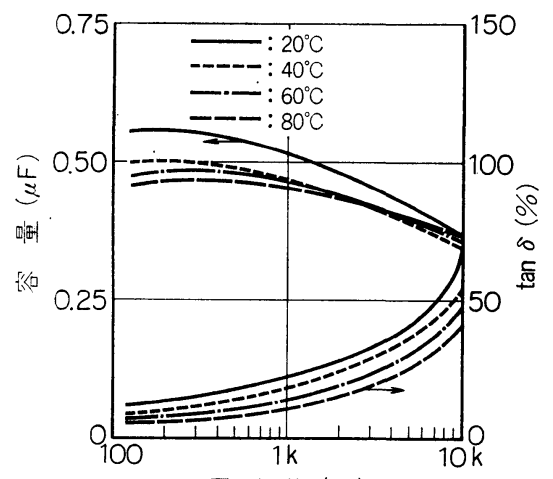

周 波 数 $(\mathrm{Hz})$

図 7 容量と $\tan \delta$ の温度特性 (成形正 $0.1 \mathrm{t}, 20$ メッシュ)

く同じである。すなわち周波数が大さくなれば，容量は 减少し, $\tan \delta$ は増した。

\section{4-4 容量比および $\tan \delta$ の周波数特性におよほすア ルミニウム粉末の粒度の影響}

粒度が大きいほど，すなわちアルミニウム粉末の粒子 が小さいほど，各周波数に打ける容量比は小さく $\tan \delta$ は大きくなった。このことは粒子の小さいほど電気的に 不安定な誘電体皮膜構造をもっていると考えられる。な ぜならば，良好な誘電体の周波数特性は周波数が増加し ても容量の変化がほとんどないからである。

\section{4-5 容量比および $\tan \delta$ の周波数特性におよはす温 度の影響}

図 9 より，低い温度の場合は高い温度より容量比は小 さく，逆に $\tan \delta$ は大さくなった。一般にコンデンサに おいては温度が高くなると，容量と $\tan \delta$ は小さくなる 特性からみて, $20^{\circ} \mathrm{C}$ の場合がもっとも容量が大きいだ けに（図 7)，それだけ周波数の影響を大きくらけると 考えられる。 $\tan \delta$ については, 容量比と違って変化す る割合をデータとして使用していないから，一般のコン

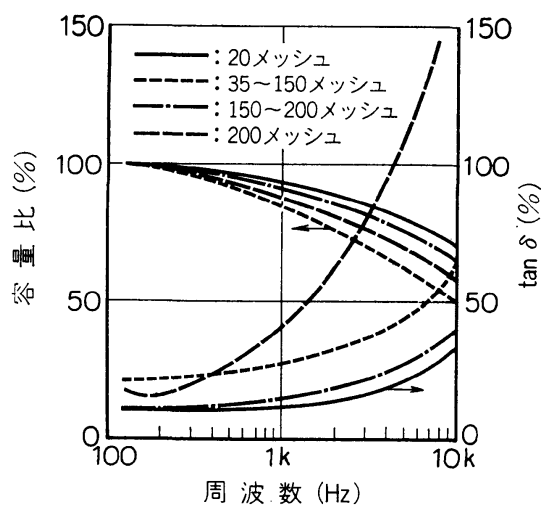

図 8 容量比と $\tan \delta$ の周波数特性 (成形压 $0.2 \mathrm{t}, 40^{\circ} \mathrm{C}$ )

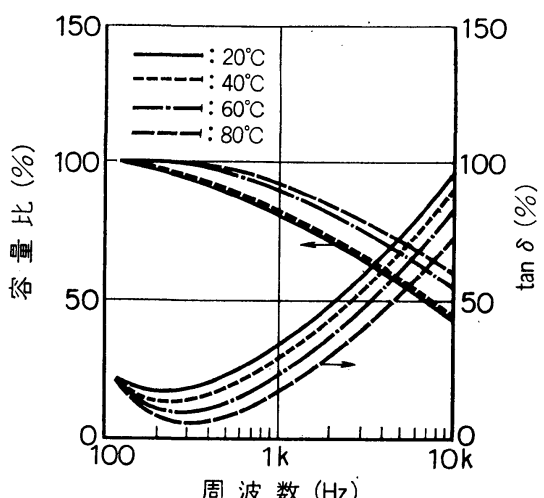

図 9 容量比と $\tan \delta$ の温度特性 (成形王 $0.1 \mathrm{t}, 200$ メッシュ)

デンサの特性と同じように低い温度を中心にして高い温 度と比較を行なえば, 当然 $\tan \delta$ の値は大きくなる。

\section{5. ま とめ}

今回の実験は前回報告したなかから，最適条件を選 び，窒素ガスふん囲気中で焼結体を，そしてさらに化成 を行なって誘電体素子を作成した。すなわちアルミニウ ム粉末の成形圧は0.1 0.2 $\mathrm{t}$, 焼結温度は $600^{\circ} \mathrm{C}$ の条件 を用いた。化成液の良否を画一的に決めることは濃度因 子といら変数を含んでいるだけになかなか困難なことが 多い。そこで今回はリン酸二水素アンモニウム溶液を専 ら化成液として用いた。この化成によってつくられた誘 電体素子に二酸化マンガンの半導体付ケを行ない, さら に銀陰極付ケを行なった。このよらにしてつくられたア ルミニウム焼結形固体電解コンデンサについて各種の電 気的特性を測定し，粒度および成形圧などの影響を調べ た。これらの測定結果からつぎのようなことがまとめら れる。

（1）電圧-電流特性（V-I 特性）には粒度の違いによ 
る影響はみられなかった。成形圧による影響は，0.2 t の場合が0. $1 \mathrm{t}$ に比べて，V-I 特性の曲線の傾斜が小さ かった。

(2) 耐電圧は成形圧0. $2 \mathrm{t}$ と0.1 t の場合は, ほとんど 影響はみられなかった。

（3）化成液にリン酸二水素フンモニウム溶液を用いた が, 濃度が $0.1 \%$ のと化成して得られた誘電体素子の 耐電圧は, 他の濃度の場合と比較してもっとも小さく表 われた。

（4）各周波数に打ける容量と $\tan \delta$ の值は，粒度の大 きいほど（粒子の小さいほど）大きく，逆に容量比は小 さくなった。

（5）低い温度は高い温度の場合より各周波数に括ける 容量比は小さく, $\tan \delta$ は大きく表われた。

（6）電圧-電流特性以外のこれまでの電気的特性の測 定值は, いずれも $0.1 \mathrm{t}$ と0.2 $\mathrm{t}$ の成形圧の相違による影
響はほとんどうけないように思われる。

本報告について，本大学，大久保芳随先生のご協力に

対し感謝の意を表します。

(1973-2-9 受理)

\section{文献}

1）大熊, 根本, 第176回東京電機大学研究談会にて発 表，（昭41.11.5）

2）大熊, 根本, 電気四学会連合大会にて発表, （昭和 42. 4.29)

3) 大熊, 根本, コンデンサ評論, 20，6，275（1967）

4 ）絵末治金技術協会，粉末治金総説，焼結機構粉末冶 金技術講座 1, 日刊工業新聞社（昭39）

5) T. H. Dedrick, A. Gerds, J. Appl. Phys, 20, 1042 (1949)

6) G. L. Martin. et al, J. Electrochem Soc 107, 332 (1960)

7 ）大熊，根本，金属表面技術，23，204（1972）

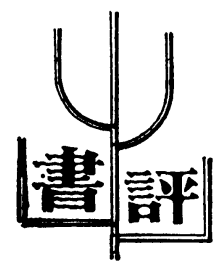

本書は昭和44年12月から「表面処理ジャーナル」誌に 連載されている「日本と世界に拈ける防錆防食の歴史」 の原始時代から1900年（明治33年）までの分をまとめた もので，この第 1 巻にひきつづき1900年から1945年まで を第 2 巻, 1945年から1965年までを第3巻として刊行さ れるすのである。

一般に歴史の書は多いが，その大部分は国家民族の栄 枯盛衰を扱った戦乱戦争が内容であり，本書のような角 度から眺めた生活文化史, 科学技術史はまれである。

考えてみれば，人類が金属を使い初めて以来防錆防食 とは無縁でいられなかったはずであり，今日の文明も金 属の恩恵なしには考兄られないことである。しかし防錆 防食はいわゆる境界学問といわれると招り関連分野む広 く，その上時間のファクターが乗ぜられる本書のような テーマには，その量的規模を想像しただけで誰もが尻込 みせざるを得ないものであった。いいかえれば，誰かが 切り拓かねばならない原野であった。

ここにクワを入れられた勇断に著者の40年にわたる錆 の研究に裏付けられた自負と執念を感じるとともにとか く安易な道に進みたがる私には無言の警策として受けと めるのである。
山本洋一著

\section{日本と世界における防錆防食の歴史}

\section{金属の生産と使用を含めて——}

表面処理ジャーナル社 B 5 版 213ページ

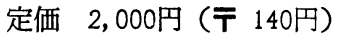

第 1 巻を読んで改めてこの感を抱くと同時に，平易に 表現された興味深い内容の連続にページをめくる楽しみ がつきない。一般のかたがたにも教養書として薦められ る。

なかでる，今日ステンレスとして鉄鋼の代表的添加元 素であるクロムが1819年ファラデーらの実験ではむしろ 鉄をさびやすくする（Cr 3\%以下）としている点や， Passivity の研究がすでに1782年ウェンツェル，1785年 ベルグマン，1787年キルワン，1790年カイルなどによっ て行なわれていたことなど注目される。

そして著者が自序で述べているように，70年代はテク ノロジーアセスメントの時代であり，いままでの科学技 術の発展を振り返ってみるためにも本書の意義は深い。

また，アルレニウスの電離説やプランク定数に対する 著者の見解が述べられている点は，歴史書として異色で あると同時に第 1 巻のハイライトとい兄よう。

ともあれ，莫大な資料を要したであろう本書が 1 人の 手で誕生されたことに敬意を表するとともに，著者がそ の後記でも述べているように, 多くの読者の協力によっ てさらに充実したものとなるための成長を続けていくこ とを期待する。

（田尻勝紀） 